Review Article

\title{
Toxicity and Microbial Degradation of Nitrobenzene, Monochloronitrobenzenes, Polynitrobenzenes, and Pentachloronitrobenzene
}

\author{
Pankaj Kumar Arora and Hanhong Bae \\ School of Biotechnology, Yeungnam University, Gyeongsan 712-749, Republic of Korea \\ Correspondence should be addressed to Pankaj Kumar Arora; arora484@gmail.com and Hanhong Bae; hanhongbae@ynu.ac.kr
}

Received 3 November 2014; Accepted 2 December 2014; Published 21 December 2014

Academic Editor: Davide Vione

Copyright (C) 2014 P. K. Arora and H. Bae. This is an open access article distributed under the Creative Commons Attribution License, which permits unrestricted use, distribution, and reproduction in any medium, provided the original work is properly cited.

Nitrobenzene and its derivatives (NBDs) are highly toxic compounds that have been released into the environment by anthropogenic activities. Many bacteria and fungi have been well-characterized for their ability to degrade NBDs. The biochemical and molecular characterization of the microbial degradation of NBDs has also been studied. In this review, we have summarized the toxicity and degradation profiles of nitrobenzene, monochloronitrobenzenes, polynitrobenzenes, and pentachloronitrobenzene. This review will increase our current understanding of toxicity and microbial degradation of NBDs.

\section{Introduction}

Nitrobenzene and its derivatives (NBDs) are a group of toxic chemicals that are widespread in the environment owing to their worldwide use [1]. Examples include nitrobenzene, 1,3-dinitrobenzene (1,3-DNB), 1,3,5-trinitrobenzene (1,3,5TNB), 2-chloronitrobenzene (2CNB), 3-chloronitrobenzene (3CNB), 4-chloronitrobenzene (4CNB), and pentachloronitrobenzene (PCNB) (Figure 1). PCNB is commonly known as Quintozene.

NBDs are widely used for the production of explosives, drugs, dyes, fungicides, and other industrial compounds [110]. Table 1 summarizes a list of applications of NBDs. The use of some derivatives of nitrobenzene has been banned or restricted in several countries. For example, use of PCNB as a fungicide has been banned in South Korea, India, Sri Lanka, Belize, Germany, Sweden, Austria, and Finland. However, restricted use of PCNB as a fungicide is permitted in Canada, the United States, Australia, New Zealand, and Israel [11]. South Korea banned PCNB in 1989 due to its toxic nature and detection of the compound in the ginseng root [12]. In Canada, the use of PCNB on recreational turf has been banned since 31 December 2010 by the Pest Management
Regulatory Agency; however, limited use of PCNB is permitted on cole crops and for ornamental bulb dipping [13]. The European Union also banned use of PCNB as a pesticide in 2000 because of the risk to nontarget organisms, operators, and consumers [11]. The Australian Pesticides and Veterinary Medicines Authority suspended PCNB approvals in April 2010 owing to the presence of a highly toxic compound, dioxin, as a contaminant [14]. The United States Environmental Protection Agency considered the risks associated with the persistence and bioaccumulative properties of PCNB in 2006 under the Food Protection Quality Act (FPQA) of 1996 and decided to restrict the use of PCNB on some crops [15].

Due to their worldwide use, NBDs are found throughout the environment in water, soil, and air. People may be exposed to NBDs via consumption of food and water containing NBDs, by dermal contact with NBDs, and by breathing air near factory sites where NBDs are used or synthesized [16]. Most of these compounds have been classified as priority pollutants by the United States Environmental Protection Agency because of their toxicity to living organisms.

Several reviews have described the toxicity and bacterial degradation of various aromatic compounds such as chlorinated nitroaromatic compounds, nitroaromatic compounds, 
<smiles>O=[N+]([O-])c1ccccc1</smiles>

Nitrobenzene<smiles>O=[N+]([O-])c1ccc(Cl)cc1</smiles>

4-Chloronitrobenzene<smiles>O=[N+]([O-])c1cccc([N+](=O)[O-])c1</smiles>

1,3-Dinitrobenzene<smiles>O=[N+]([O-])c1ccccc1Cl</smiles>

2-Chloronitrobenzene<smiles>O=[N+]([O-])c1cc([N+](=O)[O-])cc([N+](=O)[O-])c1</smiles>

1,3,5-Trinitrobenzene<smiles>O=[N+]([O-])c1cccc(Cl)c1</smiles>

3-Chloronitrobenzene<smiles>O=[N+]([O-])c1c(Cl)c(Cl)c(Cl)c(Cl)c1Cl</smiles>

Pentachloronitrobenzene

FIGURE 1: Structure of nitrobenzene and its derivatives.

nitrophenols, and chlorophenols [9, 17-20]. However, there is lack of review on the toxicity and degradation profiles of NBDs. This review was conducted to discuss the toxicity and degradation profiles of nitrobenzene, monochloronitrobenzenes, polynitrobenzenes, and PCNB.

\section{Toxicity of NBDs}

NBDs cause several harmful health effects. For example, nitrobenzene can reduce the ability of blood to carry oxygen because it causes methemoglobinemia $[6,16]$. Repeated exposure to high levels of 1,3-DNB and 1,3,5-TNB may cause anemia, development of bluish color in the skin, headache, nausea, weakness, sleepiness, vomiting, grouchiness, and dizziness [21]. Experimental studies in animals showed that 1,3-DNB and 1,3,5-TNB cause male reproductive damage and may reduce sperm production [21]. $4 \mathrm{CNB}$ has been identified as a potent hematotoxicant, whereas $2 \mathrm{CNB}$ is a potent hepatotoxicant [22].

NBDs were considered as reasonably anticipated to be human carcinogens and classified as possibly carcinogenic to humans in a report by the International Agency for Research on Cancer [6]. Several tissue specific tumors including benign and malignant lung tumors (alveolar/bronchiolar adenoma and carcinoma), benign thyroid-gland tumors (follicularcell adenoma), benign mammary-gland tumors (adenocarcinoma), liver tumors (hepatocellular adenoma), and kidney tumors (renal adenoma) have been observed in experimental animals including mice and rats because of inhalation exposure to nitrobenzene [6]. Oral exposure to 2CNB caused hepatocellular adenomas and carcinomas in rats and mice and hepatoblastomas in mice. $4 \mathrm{CNB}$ caused splenic and adrenomedullary tumors in rats and vascular tumors in mice, as well as chronic hepatotoxicity [22]. 2CNB is a genotoxic substance that has been shown to cause mutation in bacteria.

PCNB may cause skin sensitization and eye irritation in humans $[23,24]$ and it has been classified as a pesticide causing allergic contact dermatitis [24]. Experimental studies showed that there was no skin irritation in humans after a single 48-hour contact but that a second exposure 2 weeks later elicited a reaction in $26 \%$ of test subjects [23]. PCNB may damage the eye and cause conjunctivitis with corneal injury [25]. Although there have been no investigations of the chronic, reproductive, developmental, or carcinogenic effects of PCNB in humans, the long term effects of PCNB have been studied in various animals. Liver damage was observed in dogs fed with PCNB through their diets [25, 26]. Additionally, mice orally exposed to PCNB showed lethal symptoms in their offspring including renal agenesis, cleft palate, and increased fetal mortality [26]. Finally, mice exposed to PCNB via gavage developed hepatomas [27]. PCNB may bioaccumulate in the aquatic food chain and it is highly toxic to fish and invertebrates [28]. Owing to its highly toxic nature, the United States Environmental Protection Agency has classified PCNB as a priority pollutant and a possible human carcinogen. 
TABLE 1: Uses of nitrobenzene and its derivatives.

\begin{tabular}{|c|c|c|}
\hline Chemical & Uses & References \\
\hline Nitrobenzene & $\begin{array}{l}\text { Used for the production of aniline, which is the main source for } \\
\text { the synthesis of polyurethane. } \\
\text { Synthesis of chemicals such as benzidine, quinoline, } \\
\text { azobenzene, pyroxylin compounds, and isocyanates. } \\
\text { Synthesis of pesticides, rubbers, and pharmaceuticals. } \\
\text { Synthesis of dyes such as nigrosine and magenta. } \\
\text { Making greases and oils. } \\
\text { Preparation of soaps and shoe polishes. } \\
\text { Used as a solvent for cellulose ester in modifying esterification } \\
\text { of cellulose acetate and in refining lubricating oils. }\end{array}$ & {$[1,4-6]$} \\
\hline 1,3-Dinitrobenzene (1,3-DNB) & $\begin{array}{l}\text { Used in explosives. } \\
\text { Formed as a by-product during the manufacture of the } \\
\text { explosive, trinitrotoluene. } \\
\text { Used as a camphor substitute in nitrocellulose, a compound in } \\
\text { explosives and propellants. } \\
\text { Used in the production of dyes and plastics. } \\
\text { Used as an organic intermediate for m-phenylenediamine, a } \\
\text { chemical used in the synthesis of aramid fibers and spandex. } \\
\text { Used as an indicator in the detection of 17-ketosteroids. } \\
\text { Used as an electrolytic reducer in the preparation of } \\
\text { aminocresols. }\end{array}$ & {$[4,5]$} \\
\hline 1,3,5-Trinitrobenzene $(1,3,5$-TNB) & $\begin{array}{l}\text { Used as an explosive by a variety of industries and the military. } \\
\text { Used as a vulcanizing agent in the processing of natural rubber. } \\
\text { Used as an indicator in acid-base reactions in the pH range of } \\
12.0-14.0 \text {. }\end{array}$ & {$[3,5]$} \\
\hline 4-Chloronitrobenzene (4CNB) & $\begin{array}{l}\text { Used for synthesis of chemicals such as p-nitrophenol, } \\
\text { p-nitroaniline, p-aminophenol, 4-chloroaniline, 4-nitrophenol, } \\
\text { 4-nitroanisole, para-anisidine, 4-nitroaniline, } \\
\text { 6-chloro-3-nitrobenzenesulfonic acid, } \\
\text { 2,4-dinitrochlorobenzene, 3,4-dichloronitrobenzene } \\
\text { phenacetin, acetaminophen, and parathion. } \\
\text { Used for synthesis of agricultural chemicals, rubber chemicals, } \\
\text { antioxidants, oil additives, and the drug, dapsone. }\end{array}$ & {$[5,8]$} \\
\hline 2-Chloronitrobenzene (2CNB) & $\begin{array}{l}\text { Used for synthesis of para-anisidine, diaminophenol } \\
\text { hydrochloride (a photographic developer), corrosion inhibitors, } \\
\text { pigments, and other agricultural chemicals. }\end{array}$ & {$[8]$} \\
\hline 3-Chloronitrobenzene (3CNB) & Used for synthesis of 3-chloroaniline (orange GC base) & {$[7]$} \\
\hline Pentachloronitrobenzene & $\begin{array}{l}\text { Used as an organochlorine fungicide for control of various } \\
\text { fungal diseases caused by Rhizoctonia solani, Botrytis spp., } \\
\text { Aspergillus spp., Penicillium spp., Fusarium spp., Sclerotinia spp., } \\
\text { and Tilletia caries. } \\
\text { Used for soil and seed treatment against Rhizoctonia. } \\
\text { Used to inhibit slime formation in industrial water. } \\
\text { Inhibits mitotic/division and suppresses fungal sporulation. }\end{array}$ & {$[9,10]$} \\
\hline
\end{tabular}

\section{Microbial Degradation of NBDs}

Many microorganisms have been characterized for their ability to degrade NBDs [29-34]. Microbial degradation of NBDs occurs via either a reductive mode or an oxidative mode $[30,32,34]$. The reductive pathway is initiated by reduction of the nitro group of NBDs to hydroxylamines via nitroso intermediates $[30,34]$ whereas the oxidative pathway involves oxidation of NBDs by a dioxygenase or a monooxygenase followed by ring cleavage [32]. In this section, we describe microbial degradation of nitrobenzene, chloronitrobenzenes, polynitrobenzenes, and PCNB.

3.1. Microbial Degradation of Nitrobenzene. Many bacteria have been isolated and characterized based on their ability to utilize nitrobenzene as the sole carbon and energy source [30, 32, 33, 35-37]. These bacteria degraded nitrobenzene via either the reductive pathway or the oxidative pathway. The reductive pathway has been well-studied in the nitrobenzene 
mineralizing strains, Pseudomonas pseudoalcaligenes JS45 [30] and Pseudomonas putida HS12 [33]. This pathway is initiated by the reduction of nitrobenzene to hydroxylaminobenzene via nitrosobenzene by nitrobenzene nitroreductase. Another enzyme, hydroxylaminobenzene mutase, catalyzes the conversion of hydroxylaminobenzene to 2-aminophenol through Bamberger rearrangement (Figure 2). In the next step, 2-aminophenol is cleaved to 2-aminomuconic semialdehyde by 2 -aminophenol-1,6-dioxygenase and the 2-aminomuconic semialdehyde oxidized to 2 -aminomuconic acid by a dehydrogenase. The aminomuconic acid is deaminated to 4oxaloisocrotonate by 2 -aminomuconate deaminase. 4 -Oxaloisocrotonate is then decarboxylated to 2-oxopent-4-enoate by 4-oxalocrotonate decarboxylase, and further processing takes place to give pyruvate and acetyl-CoA. The oxidative pathway of nitrobenzene degradation was studied in Comamonas sp. JS765, which was isolated from an industrial waste treatment plant in New Jersey and shown to utilize nitrobenzene as the sole source for carbon, nitrogen, and energy [32]. In strain JS765, nitrobenzene is converted to catechol by the enzyme nitrobenzene dioxygenase. The catechol is then degraded by a meta-cleavage pathway via 2 -oxopent-4-enoate to pyruvate and acetyl-CoA (Figure 2).

Jin et al. [35] reported that three nitrobenzene-degrading bacterial strains, Arthrobacter sp. NB1, Serratia sp. NB2, and Stenotrophomonas sp. NB3 isolated from contaminated sludge, utilized nitrobenzene as the sole source of carbon and nitrogen at a concentration of $400 \mathrm{mg} / \mathrm{L}$. Coculture of these three strains enhanced the degradation of nitrobenzene compared to the pure culture. The immobilized cells of Micrococcus luteus degraded nitrobenzene more efficiently under various stress conditions, including alkali and acid conditions, high temperature, and high salinity [36]. Another bacterium isolated from aerobic granular sludge, Klebsiella ornithinolytica strain NB1, utilized nitrobenzene as the sole carbon and nitrogen source and degraded it completely up to the concentration of $1000 \mathrm{mg} / \mathrm{L}$ [37]. Strain NB1 was also able to degrade nitrobenzene up to the concentration of $600 \mathrm{mg} / \mathrm{L}$ in the presence of $3 \% \mathrm{NaCl}$ [37]. $\mathrm{Li}$ et al. [38] showed that a psychrotrophic bacterium isolated from river sediments, Pseudomonas putida, was capable of degrading $20 \mathrm{mg} / \mathrm{L}$ nitrobenzene completely from 2.5 to $35^{\circ} \mathrm{C}$ with an optimum temperature of $25^{\circ} \mathrm{C}$. A halophilic bacterium isolated from nitrobenzene-contaminated saline wastewater, Myroides odoratimimus strain Y6, was capable of degrading nitrobenzene at $7 \% \mathrm{NaCl}$ [39]. Liu et al. [40] studied the biodegradation of high concentrations of nitrobenzene by a nitrobenzene-degrading bacterium, Pseudomonas corrugate embedded in peat-phosphate esterified polyvinyl alcohol, and observed that embedded cells were better degraders than free cells. Wu et al. [41] reported that Pseudomonas sp. strain a3 degraded nitrobenzene through the release of ammonium ions and observed that the immobilized cells of Pseudomonas were more capable of degrading nitrobenzene in acidic ( $\mathrm{pH} 4-$ $5)$ and highly saline $(10 \% \mathrm{NaCl})$ environments than free cells. Wei et al. [42] reported nitrobenzene degradation by three bacteria (Bacillus subtilis, Pseudomonas mendocina, and Klebsiella pneumoniae) using pure culture or coculture. Further, they found that a combination of these bacteria degraded nitrobenzene more rapidly than pure culture.

A few bacteria did not utilize nitrobenzene as the sole source of carbon and energy, but they transformed nitrobenzene in the presence of additional carbon source $[43,44]$. The nitrobenzene transformation was correlated with the induction of enzymes involved in the degradation of other nitroaromatic or aromatic compounds. For example, 3-nitrophenol induced cells of Pseudomonas putida 2NP8 exhibited cometabolic transformation of nitrobenzene to ammonia, nitrosobenzene, and hydroxylaminobenzene, suggesting the involvement of 3-nitrophenol nitroreductase [44]. Haigler and Spain [43] studied biotransformation of nitrobenzene by toluene induced cells of several strains of Pseudomonas. Pseudomonas putida F1 and Pseudomonas sp. strain JS150 transformed nitrobenzene to 3-nitrocatechol by a dioxygenase [43]. Pseudomonas mendocina KR-1 transformed nitrobenzene to a mixture of 3-nitrophenol (10\%) and 4-nitrophenol (60\%) [43], while Pseudomonas pickettii PKO1 transformed nitrobenzene to 3- and 4-nitrocatechol via 3- and 4-nitrophenol [43]. A cyanobacterium, Microcystis aeruginosa, transformed nitrobenzene to aniline by nitrobenzene reductase [45].

Li et al. [46] investigated changes in bacterial communities in the Songhua River sediments in Northeastern China, which became contaminated with nitrobenzene following explosion of an aniline production factory in November 2005. The results of their study showed that the bacterial communities of the river sediments drastically changed because of nitrobenzene contamination. They concluded that members of Comamonadaceae and Clostridium spp. are dominant strains that may be involved in the biodegradation of nitrobenzene in contaminated river environments [46].

The degradation of nitrobenzene was also studied in fungi [47-50]. Chunli et al. [49] isolated a nitrobenzene mineralizing yeast, Rhodotorula mucilaginosa strain $\mathrm{Z1}$, from nitrobenzene-contaminated sludge. This organism was able to utilize nitrobenzene as a sole source of carbon, nitrogen, and energy under aerobic conditions. Zheng et al. [50] studied degradation of nitrobenzene by polyurethane-immobilized cells of Rhodotorula mucilaginosa $\mathrm{Z1}$ and reported that polyurethane-immobilized cells of strain $\mathrm{Z1}$ had higher tolerance of acid, alkali, saline, and hot conditions than free cells. Zhang et al. [48] reported the limited degradation (80\%) of nitrobenzene by white rot fungi when the nitrobenzene concentration was kept under $150 \mathrm{mg} \cdot \mathrm{L}^{-1}$. Levin et al. [47] reported that the white rot basidiomycete Trametes trogii removed more than $90 \%$ of nitrobenzene $\left(250-500 \mathrm{mg} \cdot \mathrm{L}^{-1}\right)$ within $12-24$ days.

Dickel et al. [51] reported the complete degradation of nitrobenzene by mixed cultures using a sequential anaerobicaerobic treatment process. In a fixed-bed column, nitrobenzene was anaerobically reduced to aniline by cells of sewage sludge. Further degradation of aniline was achieved by aerobic treatment using activated sludge as inoculum [51]. Hua et al. [52] studied the effects of salinity and six metal ions including $\mathrm{Fe}^{3}, \mathrm{Ni}^{2+}, \mathrm{Zn}^{2+}, \mathrm{Al}^{3+}, \mathrm{Cr}(\mathrm{VI})$, and $\mathrm{Cu}^{2+}$ on anaerobic degradation of nitrobenzene and determined 


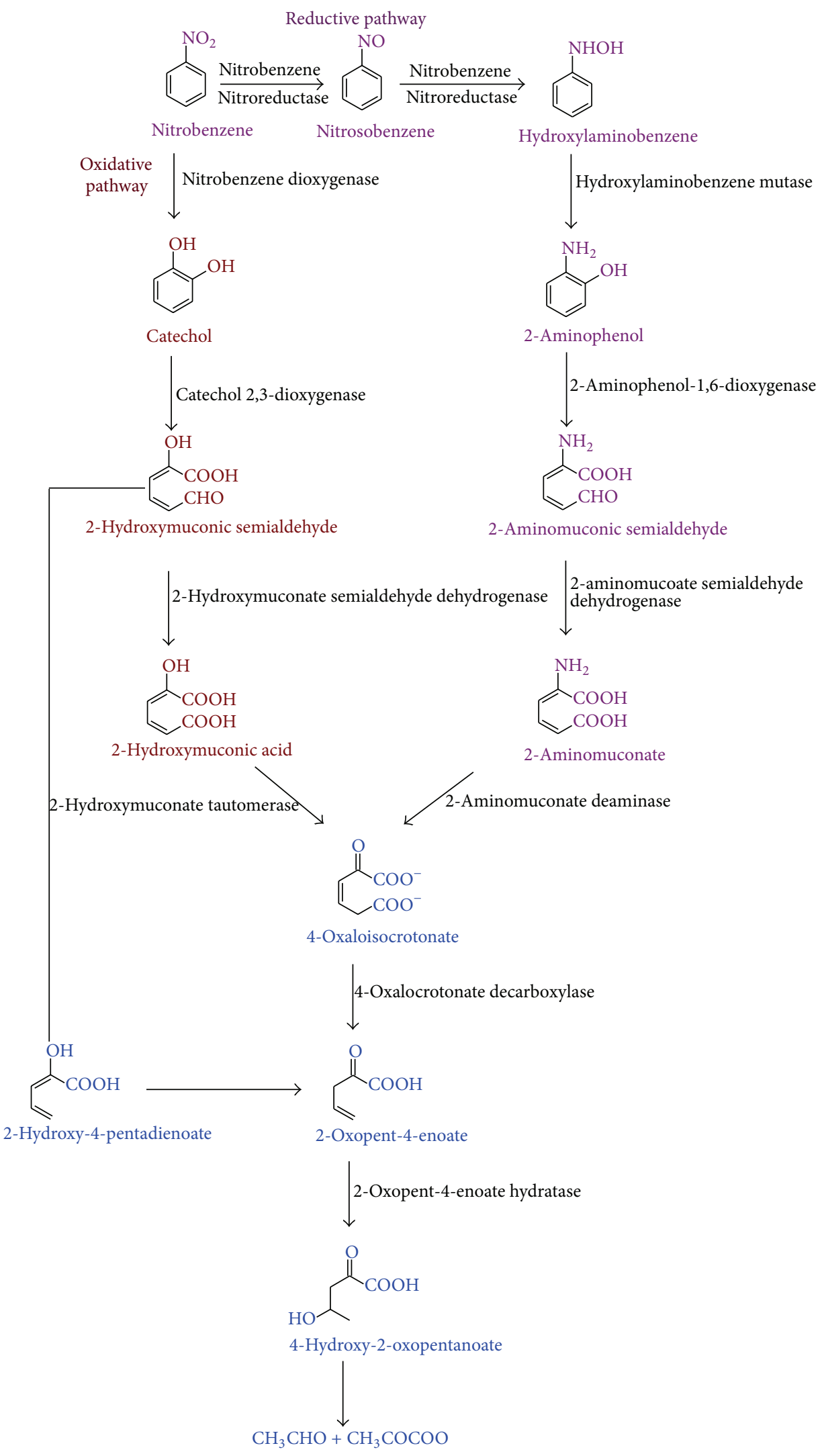

FiguRE 2: Degradation pathways of nitrobenzene (adapted from Ju and Parales [20]). 


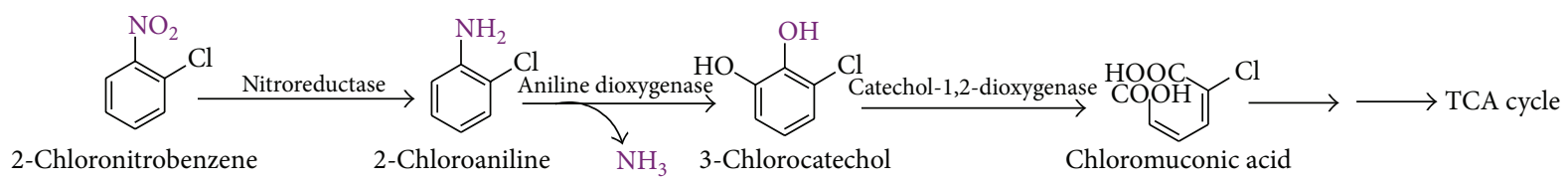

(a)

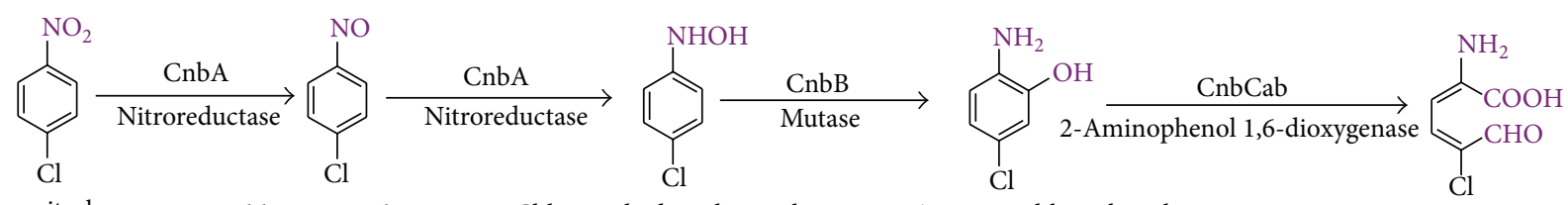
semialdehyde

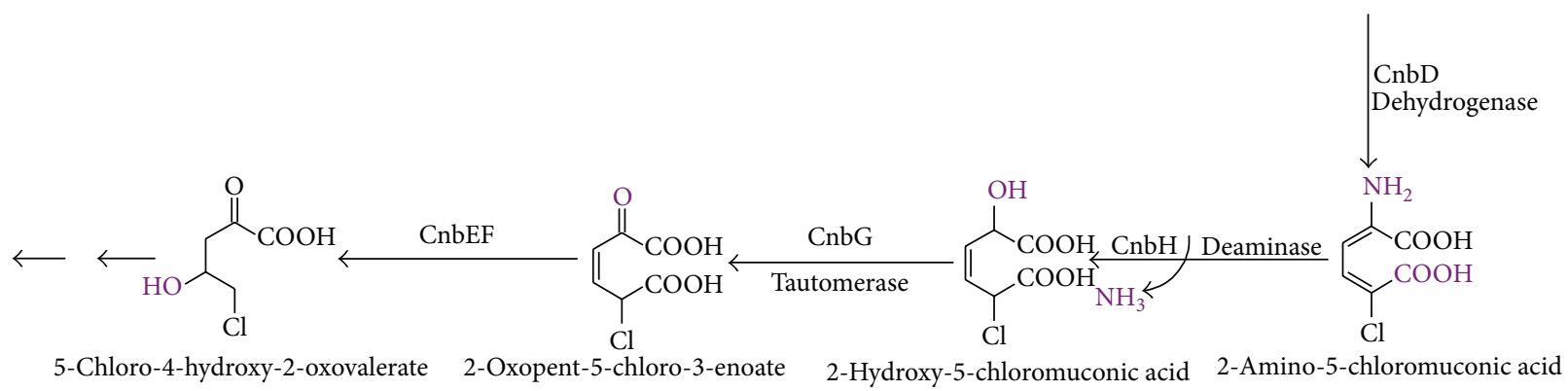

(b)

FIGURE 3: Degradation pathway of 2-chloronitrobenzene (a) and 4-chloronitrobenzene (b) (adapted from Arora et al. [9]).

that the optimum salinity for nitrobenzene degradation was between $0.25 \%$ and $1 \%$. The optimum mass concentrations of $\mathrm{Fe}^{3+}, \mathrm{Ni}^{2+}, \mathrm{Zn}^{2+}, \mathrm{Al}^{3+}$, and $\mathrm{Cr}(\mathrm{VI})$ enhanced nitrobenzene degradation; however, high concentrations of $\mathrm{Fe}^{3+}, \mathrm{Ni}^{2+}$, $\mathrm{Zn}^{2+}, \mathrm{Al}^{3+}$, and $\mathrm{Cr}(\mathrm{VI})$ inhibited the nitrobenzene degradation [52].

\subsection{Microbial Degradation of Monochloronitrobenzenes.} Monochloronitrobenzenes are chlorinated derivatives of nitrobenzene. Examples include 2-chloronitrobenzene (2CNB), 3-chloronitrobenzene (3CNB), and 4-chloronitrobenzene $(4 \mathrm{CNB})$. Few bacteria are known to utilize monochloronitrobenzene as their sole sources of carbon and energy. Liu et al. [53] reported that Pseudomonas stutzeri ZWLR 2-1 used 2CNB as its sole source of carbon and energy and mineralized it through formation of 3-chlorocatechol. The further degradation of 3-chlorocatechol proceeded via the ortho-ring cleavage pathway $[9,54]$. The degradation pathway of 2CNB was also studied in Pseudomonas putida OCNB-1, which utilizes it as the sole source of carbon and energy [55]. Initially, a chloronitrobenzene reductase catalyzed the reduction of $2 \mathrm{CNB}$ to chloroaniline, which was further deoxygenated to 3-chlorocatechol by aniline dioxygenase (Figure 3(a)). 3-Chlorocatechol was further degraded via 3-chloromuconic acid by catechol-1,2-dioxygenase [55].

The degradation pathway of $4 \mathrm{CNB}$ was studied in Comamonas sp. strain CNB-1 [56], Pseudomonas putida ZWL73 [57], and Comamonas sp. strain LW1 [58], which utilized $4 \mathrm{CNB}$ as the sole source of carbon and energy. Initially, a nitroreductase reduced $4 \mathrm{CNB}$ into 4-chloro1-hydroxylaminobenzene which was further degraded to 2-amino-5-chlorophenol (2A5CP) by a hydroxylaminobenzene mutase. The $2 \mathrm{~A} 5 \mathrm{CP}$ was then cleaved by 2 -aminophenol 1,6-dioxygenase to form 2-amino-5-chloromuconic acid which was further degraded via TCA cycle intermediates (Figure 3(b)).

The aerobic biotransformation of chloronitrobenzenes to the corresponding chloroanilines has been observed in a few Pseudomonas species [59, 60]. Schackmann and Muller [59] reported transformation of $4 \mathrm{CNB}$ to 4 -chloroaniline, $\mathrm{N}$ acetyl-4-chloroaniline, and 4-chloronitrosobenzene by the resting cells of Pseudomonas sp. strain CBS3. Pseudomonas acidovorans CA50 cometabolically transformed 2CNB, $4 \mathrm{CNB}$, and $4 \mathrm{CNB}$ into corresponding chloroanilines (CAs), which were further mineralized by the same strain via the formation of catechol [60].

A few researchers studied $4 \mathrm{CNB}$ degradation by a consortium of selected bacteria [33, 61]. For example, Zhang et al. [61] investigated the degradation of $4 \mathrm{CNB}$ by coculture of two bacteria isolated from activated sludge, Sphingomonas sp. strain CNB3 and Burkholderia sp. strain CAN6. Sphingomonas sp. strain CNB3 transformed 4CNB to 4chloroaniline but was unable to degrade 4-chloroaniline. Conversely, strain CAN6 was able to degrade 4-chloroaniline but was unable to degrade 4CNB [61]. For the complete degradation of $4 \mathrm{CNB}$, both strains were grown together and a degradation pathway was studied. First, 4CNB was converted to 4-chloroaniline, which was further converted to 2-amino-5-chlorophenol. 4-Chloroaniline and 2-amino-5chlorophenol were further degraded via the classical orthocleavage and modified ortho-cleavage pathways [61]. Park et al. [33] achieved the complete degradation of $3 \mathrm{CNB}$ and 


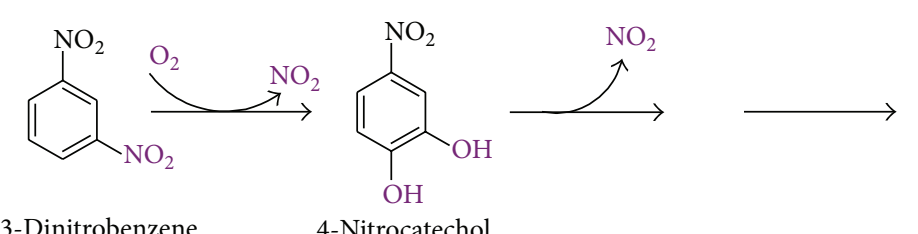

(a)

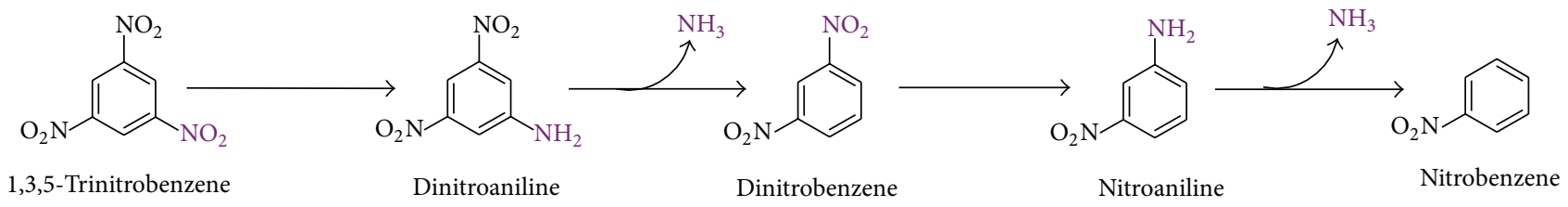

(b)

FIGURE 4: Degradation pathway of 1,3-dinitrobenzene (a) and 1,3,5-trinitrobenzene (b).

4CNB by biochemical cooperation between $P$. putida HS12 and Rhodococcus sp. HS51. Initially, strain HS12 converted CNBs to chlorohydroxyacetanilides via the process of reduction and subsequent acetylation. Later, strain HS51 degraded chlorohydroxyacetanilides via the release of ammonia and chloride.

The degradation pathway of 4-chloronitrobenzene was also studied in a yeast, Rhodosporidium sp. [62]. The degradation pathway was initiated by reduction of $4 \mathrm{CNB}$ to chlorohydroxylaminobenzene via chloronitrosobenzene. Further degradation of chlorohydroxylaminobenzene occurred via three routes. Specifically, chlorohydroxylaminobenzene was reduced to 4-chloroaniline, which was acetylated to a major transformation product, 4-chloroacetanilide. In another route, hydroxylaminobenzene underwent Bamberger rearrangement to produce aminophenol, which was further acetylated to acetanilide. In the third route, chlorohydroxylaminobenzene was directly acetylated to 4-chloro-2-hydroxyacetanilide [62].

3.3. Microbial Degradation of Polynitrobenzenes. Polynitrobenzenes are synthetic compounds with two or more nitro groups at the benzene rings. Examples include 1,3-dinitrobenzene (1,3-DNB) and 1,3,5-trinitrobenzene (1,3,5-TNB). A phenol-adapted mixed bacterial culture containing Pseudomonas as the predominant species utilized 1,3-DNB and $1,3,5-\mathrm{TNB}$ as the sole source of carbon and degraded $100 \mathrm{mg} / \mathrm{L}$ 1,3-DNB and 1,3,5-TNB under aerobic conditions. The rate of the degradation of $1,3,5$-TNB was faster than that of $1,3-$ DNB [63]. McCormick et al. [64] studied the reductive pathway of several nitroaromatic compound including 1,3,5-TNB and 1,3-DNB in the presence of enzyme cells from Veillonella alcalescens. The pathway proceeded through a nitroso intermediate to hydroxylamino compounds. Further reduction yielded amino compounds.

Mitchell and Dennis [65] studied microbial degradation of 1,3-DNB in Tennessee River water samples collected downstream from a munitions production facility in Chattanooga, Tennessee, as well as in enrichment cultures developed from the samples. They observed complete microbial degradation of 1,3-DNB after 21 days of incubation of $5 \mu \mathrm{g} / \mathrm{mL} 1,3-\mathrm{DNB}$ with river water samples [65]. They reported that microorganisms from the Tennessee River utilized 1,3-DNB as a sole carbon source and mineralized the compound. The halflife of 1,3-DNB degradation in Tennessee River samples was one day at $25^{\circ} \mathrm{C}$ with $1,000,000 \mathrm{CFU} / \mathrm{mL}$. The half-life of 1,3 $\mathrm{DNB}$ in enrichment cultures grown on 1,3-DNB was less than 10 days. The Tennessee River microorganisms degraded $1,3-\mathrm{DNB}$ more rapidly under natural conditions than in enrichment cultures.

Dey et al. [66] isolated sixteen microorganisms from soil exposed to the waste water effluent from 1,3-DNB manufacture. These microorganisms belonged to nine different genera including Streptomyces, Micrococcus, Staphylococcus, Micromonospora, Candida, Klebsiella, Vibrio, Aspergillus, and Bacillus and degraded 1,3-DNB in synthetic media as well as in waste under aerobic conditions. In the synthetic medium, the total degradation by these microbes varied from $32 \%$ to $87 \%$ and $35 \%$ to $92 \%$ under stationary and shake culture conditions, respectively. The maximum degradation percentage was observed in the case of Streptomyces aminophilus, followed by Streptomyces cacaoi, Micromonospora cabali, and Micrococcus colpogenes [66]. The degradation of 1,3-DNB by these microbes was also studied in 1,3-DNB manufacturing waste, and the percentage reduction in chemical oxygen demand (COD) ranged from 17 to $55 \%$ and from 19 to $53 \%$ under shake and stationary culture conditions, respectively. The maximum reduction in COD was observed in $M$. colpogenes followed by S. aminophilus, S. cacaoi, and M. cabali [66].

Dickel and Knackmuss [67] isolated a 1,3-dinitrobenzenedegrading bacterium, Rhodococcus strain QT-1, from nitroaromatic contaminated soil under nitrogen limiting conditions. The induced cells of strain QT-1 metabolized 1,3-DNB via the formation of nitrocatechol and released 2 moles of nitrite ions per mole of 1,3-DNB (Figure 4(a)). The characteristic feature of this strain was that it was capable of degrading 1,3 -DNB in the presence of high amounts of ammonia.

Boopathy et al. [68] studied the transformation of trinitrobenzene by a Pseudomonas consortium that utilized 
trinitrobenzene as the sole source of nitrogen, but not sole source of carbon. Dinitroaniline, dinitrobenzene, nitroaniline, nitrobenzene, and ammonia were identified as the major intermediates during the degradation of trinitrobenzene by the consortia [68]. The bacterial consortium first reduced trinitrobenzene to dinitroaniline, which was further reductively deaminated to dinitrobenzene. The dinitrobenzene was then finally transformed to nitrobenzene via reduction and subsequent deamination (Figure 4(b)). Davis et al. [69] isolated an aerobic bacterium, Pseudomonas vesicularis, from soil contaminated with 2,4,6-trinitrotoluene and 1,3,5trinitrobenzene (TNB). This bacterium used TNB as its nitrogen source and transformed it to nitrobenzene via dinitroaniline, dinitrobenzene, and nitroaniline.

3.4. Microbial Degradation of PCNB. Earlier studies of PCNB biodegradation showed anaerobic degradation of PCNB [70, 71]. Murthy and Kaufman [70] reported anaerobic degradation of PCNB in flooded and moist soil. They found that pentachloroaniline (PCA) was the principal degradation product, whereas pentachlorothioanisole (PCTA) was more abundant in flooded soil than moist soil [9]. Pentachlorophenol (PCP) was also detected as a degradation product [9]. The transformation of PCBN into 3-chloroaniline via the formation of PCA, 2,3,4,5-tetrachloroaniline, 3,4,5-trichloroaniline, and 3,5-dichloroaniline was observed in anaerobic estuarine sediment collected from the Tsurumi River, Japan [9, 71]. Tas and Pavlostathis [72] studied the reductive biotransformation of PCNB in a mixed methanogenic culture derived from contaminated sediment. The initial step involves reduction of PCNB to PCA, which was sequentially dehalogenated to 3-chloroaniline and 4-chloroaniline via the formation of 2,3,4,5-tetrachloroaniline, 2,3,5,6-tetrachloroaniline, 2,4,5-trichloroaniline, 2,3,5-trichloroaniline, 2,4-dichloroaniline, 2,5-dichloroaniline, and 3,5-dichloroaniline $[9,72]$.

Murphy et al. [73] reported the transformation of PCNB to PCA and PCTA by a protozoan, Tetrahymena thermophila with detection of the activities of glutathione transferase and thiol S-methyltransferase [9]. Chacko et al. [74] studied the conversion of PCNB to PCA by Streptomyces aureofaciens. Nakanishi and Oku [75] also reported the transformation of PCNB to PCA and PCTA by Fusarium oxysporum and Fusarium dycopensia. Park et al. [33] studied the transformation of PCNB into PCA, tetrachloroaniline, tetracholorothiophenol, PCTA, and pentachloroanisole by the four soil micromycetes, Mucor racemosus, Sporothrix cyanescens, Paecilomyces farinosus, and Pithomyces chartarum [9]. Lièvremont et al. [76] demonstrated that $M$. racemosus and $S$. cyanescens were better PCNB degraders than Rhizopus arrhizus. Lièvremont et al. [77] reported that fungal mycelia may remove PCNB from aqueous solution via the process of absorption [9].

Takagi et al. [78, 79] isolated a PCNB-degrading bacterium Nocardioides sp. PD653 from an enrichment culture in a soil-charcoal perfusion system that degraded PCNB and hexachlorobenzene via pentachlorophenol, tetrachlorohydroquinone, and 2,6-dichlorohydroquinone (Figure 5). Another PCNB-degrading bacterium Labrys portucalensis pcnb-21 was able to degrade $100 \mathrm{mg} \mathrm{kg}^{-1}$ PCNB in sterile and nonsterile soils $[9,80]$. This strain may be used for bioremediation of PCNB-contaminated soil [9].

\section{Molecular Characterization of Biodegradation of Nitrobenzene}

The genes ( $n b z A a, n b z A b, n b z A c$, and $n b z A d)$ encoding nitrobenzene dioxygenase (NBDO), which catalyzes the first step of degradation of nitrobenzene, were cloned and characterized from Comamonas sp. strain JS765 [81]. NBDO is a multicomponent protein consisting of three subunits: (i) a reductase (encoded by $n b z A a$ ), (ii) a ferredoxin (encoded by $n b z A b$ ), and (iii) an oxygenase [82]. Oxygenase is a hexameric protein containing three $\alpha$-subunits and three $\beta$-subunits encoded by the nbzAc and nbzAd genes, respectively. High sequence homology was observed between the components of NBDO and the naphthalene family of the Rieske nonheme iron oxygenases, which include the 2-nitrotoluene dioxygenase from Acidovorax sp. JS42 [81].

The genes (cnbABCaCbDEFGH, cnbZ) responsible for degradation of 4-chloronitrobenzene were found in the pCNB1 $(89 \mathrm{~kb})$ plasmid from Comamonas strain CNB-1 [83]. Wu et al. [56] cloned and expressed seven genes, $c n b A$, $c n b B, c n b C a, c n b C b, c n b D, c n b G$, and $c n b H$, in recombinant Escherichia coli, which were identified as encoding 4CNB-nitroreductase (CnbA), 1-hydroxylaminobenzene mutase (CnbB), 2-aminophenol 1,6-dioxygenase (CnbCab), 2-amino-5-chloromuconic semialdehyde dehydrogenase (CnbD), 2-hydroxy-5-chloromuconic acid tautomerase, and 2-amino-5-chloromuconic acid deaminase ( $\mathrm{CnbH})$. Zhang et al. [83] cloned and simultaneously expressed two genes in $E$. coli, $c n b \mathrm{E}$ and $c n b \mathrm{~F}$. The $\mathrm{CnbE}$ and $\mathrm{CnbF}$ together catalyzed the conversion of 2-oxohex-4-ene-5-chloro-1,6-dioate into 2-oxo-4-hydroxy-5-chloro-valeric acid in the degradation pathway of $4 \mathrm{CNB}$. Liu et al. [84] reported characterization of the gene ( $c n b Z$ ) encoding a deaminase catalyzing the conversion of 2-amino-5-chloromuconate to 2-hydroxy-5chloromuconate. Xiao et al. [85] characterized the genes encoding chloronitrobenzene nitroreductase (CnbA) and hydroxylaminobenzene mutase $(\mathrm{CnbB})$ from another $4 \mathrm{CNB}$ degrading bacterium, Pseudomonas putida ZWL73. The genes involved in 4CNB degradation in both Comamonas testosteroni CNB-1 and Pseudomonas putida ZWL73 are located on large plasmids (pCNB-1 and pZWL73, resp.) $[86,87]$. In plasmid pCNB-1, the $4 \mathrm{CNB}$-degrading genes reside within a very large transposon TnCNB.

\section{Conclusions}

Several NBDs-degrading microbes have been well-characterized and the whole genome sequences of these microbes may explore the genetics of microbial degradation of NBDs. For example, the whole genome of PCNB-degrading bacteria may be used to explore the mechanism of the dehalogenation of this highly chlorinated complex compound, as well as investigate the degradation pathways of similar compounds. 


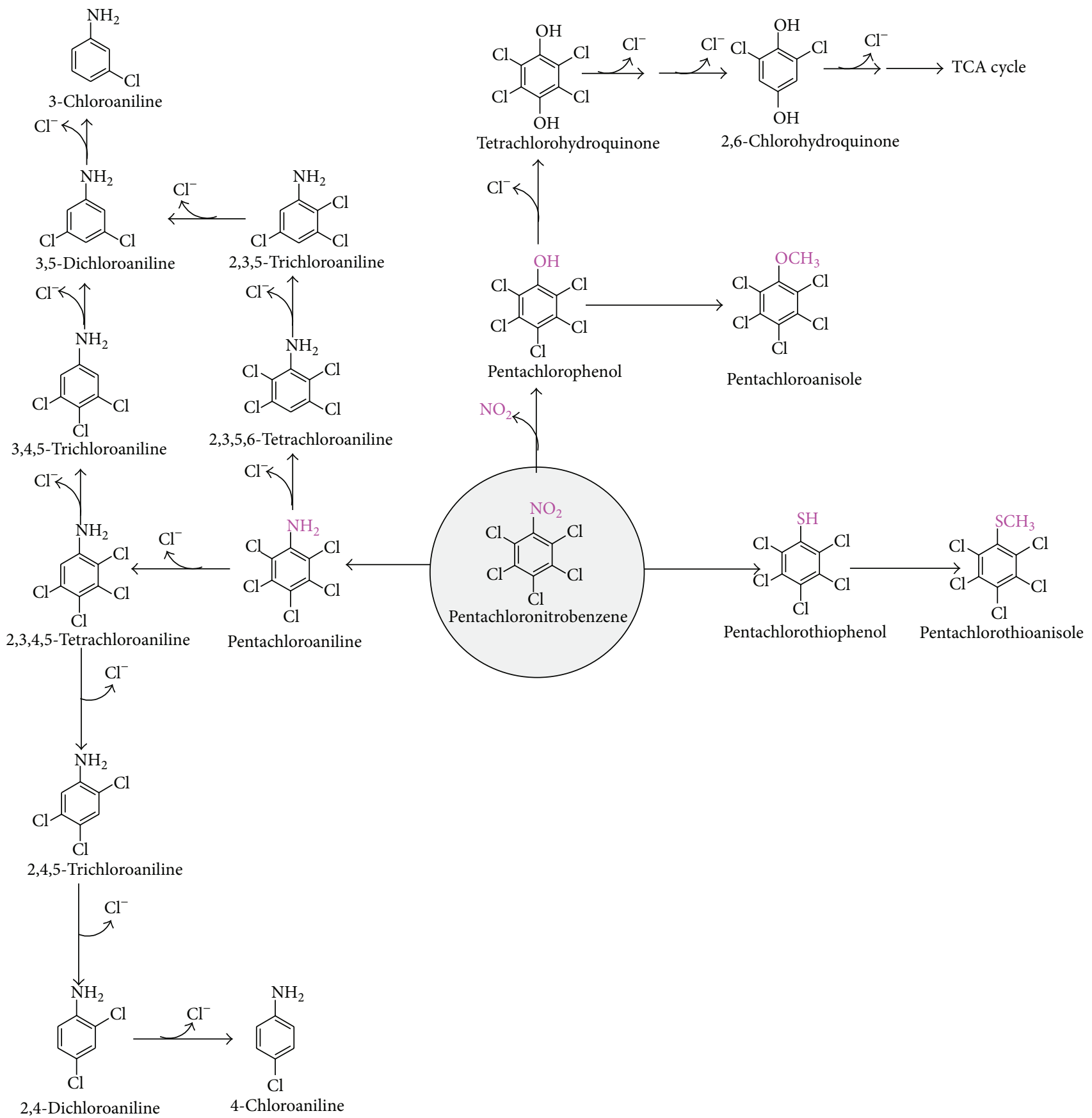

FIGURE 5: Degradation pathways of pentachloronitrobenzene (adapted from Arora et al. [9]).

The degradation pathways of nitrobenzene and chloronitrobenzenes have been characterized at molecular and biochemical levels. Similar research should be carried out for microbial degradation of 1,3-DNB and 1,3,5-TNB. The enzymes and genes involved in the degradation of 1,3DNB and 1,3,5-TNB should be characterized from 1,3-DNBand 1,3,5-TNB-degrading microbes. Furthermore, more 1,3DNB- and 1,3,5-TNB-degrading microbes should be isolated and characterized.

\section{Conflict of Interests}

The authors declare that they have no competing interests.

\section{Authors' Contribution}

Pankaj Kumar Arora collected all the relevant data, arranged the review structure, drafted the paper, and prepared all figures. Hanhong Bae corrected and revised the paper. All authors read and approved the final paper. 


\section{Acknowledgment}

This study was carried out with the support of the "Forest Science \& Technology Projects (Project no. S121414L030110)" provided by the Korea Forest Service.

\section{References}

[1] Agency for Toxic Substances and Disease Registry (ATSDR), Toxicological Profile for Nitrobenzene, U.S. Department of Health and Human Services, Public Health Service, Atlanta, Ga, USA, 1990.

[2] R. J. Sr. Lewis, Ed., Hawley's Condensed Chemical Dictionary, John Wiley \& Sons, New York, NY, USA, 13th edition, 1997.

[3] M. J. O’Neil, Ed., The Merck Index-An Encyclopedia of Chemicals, Drugs, and Biologicals, Merck and Co., Whitehouse Station, NJ, USA, 13th edition, 2001.

[4] R. J. Lewis Sr., Ed., Hawley's Condensed Chemical Dictionary, John Wiley \& Sons, New York, NY, USA, 15th edition, 2007.

[5] Hazardous Substances Data Bank (HSDB), MEDLARS Online Information Retrieval System, National Library of Medicine, 2009.

[6] National Toxicology Program (NTP), "Nitrobenzene," in Report on Carcinogens, pp. 294-296, US Department Health and Human Services, Public Health Service, 12th edition, 2011.

[7] G. Booth, Nitro Compounds, Aromatic, Ullmann's Encyclopedia of Industrial Chemistry, Wiley-VCH, Weinheim, Germany, 2000.

[8] International Agency for Research on Cancer (IARC), "2Chloronitrobenze, 3-chloronitrobenzene and 4-chloronitrobenzene," in IARC Monographs on the Evaluation of the Carcinogenic Risks to Humans, vol. 65, pp. 263-296, World Health Organization, Lyon, France, 1996.

[9] P. K. Arora, C. Sasikala, and C. V. Ramana, "Degradation of chlorinated nitroaromatic compounds," Applied Microbiology and Biotechnology, vol. 93, no. 6, pp. 2265-2277, 2012.

[10] D. O. Tas and S. G. Pavlostathis, "Occurrence, toxicity, and biotransformation of pentachloronitrobenzene and chloroanilines," Critical Reviews in Environmental Science and Technology, vol. 44, no. 5, pp. 473-518, 2014.

[11] Environmental Risk Management Authority (ERMA), Decision: Application for the Reassessment of a Hazardous Substance under Section 63 of the Hazardous Substances and New Organisms Act 1996: Water Dispersible Granule or Wettable Powder Containing $750 \mathrm{~g} / \mathrm{kg}$ Quintozene, Environmental Risk Management Authority (ERMA), Wellington, New Zealand, 2011.

[12] S.-K. Shin, J.-E. Kim, G.-S. Kwon et al., "Isolation and identification of a pentachloronitrobenzene (PCNB) degrading bacterium Alcaligenes xylosoxidans PCNB-2 from agricultural soil," The Journal of Microbiology, vol. 41, no. 2, pp. 165-168, 2003.

[13] Pest Management Regulatory Agency (PMRA), "Re-evaluation decision RVD2010-06," 2010.

[14] Australian Pesticides and Veterinary Medicines Authority (APVMA), "Understanding the APVMA's decision on quintozene," 2012.

[15] U.S. Environmental Protection Agency Reregistration (US EPA), Eligibility Decision for Pentachloronitrobenzene, Office of Pesticide Programs, Washington, DC, USA, 2006.

[16] U. S. Environmental Protection Agency (US EPA), "Health and environmental effects profile for nitrobenzene," Tech.
Rep. ECAO-CIN-P145, Office of Solid Waste and Emergency Response, Washington, DC, USA, 1985.

[17] P. K. Arora and H. Bae, "Bacterial degradation of chlorophenols and their derivatives," Microbial Cell Factories, vol. 13, no. 1, article 31, 2014.

[18] P. K. Arora, A. Srivastava, and V. P. Singh, "Bacterial degradation of nitrophenols and their derivatives," Journal of Hazardous Materials, vol. 266, pp. 42-59, 2014.

[19] P. K. Arora and H. Bae, "Role of dehalogenases in aerobic bacterial degradation of chlorinated aromatic compounds," Journal of Chemistry, vol. 2014, Article ID 157974, 10 pages, 2014.

[20] K.-S. Ju and R. E. Parales, "Nitroaromatic compounds, from synthesis to biodegradation," Microbiology and Molecular Biology Reviews, vol. 74, no. 2, pp. 250-272, 2010.

[21] Agency for Toxic Substances and Disease Registry (ATSDR), Toxicological profile for 1, 3-dinitrobenzene and 1, 3, 5-trinitrobenzene, U.S. Department of Health and Human Services, Public Health Service, Atlanta, Ga, USA, 1995.

[22] M. Matsumoto, S. Aiso, Y. Umeda et al., "Thirteen-week oral toxicity of para- and ortho- chloronitrobenzene in rats and mice," The Journal of Toxicological Sciences, vol. 31, no. 1, pp. 922, 2006.

[23] Extension Toxicology Network (EXTOXNET), Hazardous Substances Databank, Medlars Management Section, Bethesda, Md, USA, 1993.

[24] M. A. Kamrin, Pesticide Profiles: Toxicity, Environmental Impact, and Fate, Lewis Publishers, Boca Raton, Fla, USA, 1997.

[25] W. J. Hayes and E. R. Laws Jr., Eds., Handbook of Pesticide Toxicology, Classes of Pesticides, vol. 3, Academic Press, New York, NY, USA, 1991.

[26] National Research Council (NRC), Drinking Water \& Health, vol. 1, National Academy Press, Washington, DC, USA, 1977.

[27] International Agency for Research on Cancer ( IARC), IARC Monographs on the Evaluation of the Carcinogenic Risk of Chemicals to Man: Some Organochlorine Pesticides, vol. 5, World Health Organization, Lyon, France, 1974.

[28] T. L. Metcalfe, P. J. Dillon, and C. D. Metcalfe, "Effects of formulations of the fungicide, pentachloronitrobenzene on early life stage development of the Japanese medaka (Oryzias latipes)," Chemosphere, vol. 71, no. 10, pp. 1957-1962, 2008.

[29] C. L. Zheng, J. T. Zhou, L. H. Zhao, H. Lu, B. C. Qu, and J. Wang, "Isolation and characterization of a nitrobenzene degrading Streptomyces strain from activated sludge," Bulletin of Environmental Contamination and Toxicology, vol. 78, no. 2, pp. 163-167, 2007.

[30] S. F. Nishino and J. C. Spain, "Degradation of nitrobenzene by a Pseudomonas pseudoalcaligenes," Applied and Environmental Microbiology, vol. 59, no. 8, pp. 2520-2525, 1993.

[31] R. M. Torres, C. Grosset, R. Steiman, and J. Alary, "Liquid chromatography study of degradation and metabolism of pentachloronitrobenzene by four soil micromycetes," Chemosphere, vol. 33, no. 4, pp. 683-692, 1996.

[32] S. F. Nishino and J. C. Spain, "Oxidative pathway for the biodegradation of nitrobenzene by Comamonas sp. strain JS765," Applied and Environmental Microbiology, vol. 61, no. 6, pp. 2308-2313, 1995.

[33] H.-S. Park, S.-J. Lim, Y. K. Chang, A. G. Livingston, and H.S. Kim, "Degradation of chloronitrobenzenes by a coculture of Pseudomonas putida and a Rhodococcus sp," Applied and Environmental Microbiology, vol. 65, no. 3, pp. 1083-1091, 1999. 
[34] H.-S. Park and H.-S. Kim, "Identification and characterization of the nitrobenzene catabolic plasmids pNB1 and pNB2 in Pseudomonas putida HS12," Journal of Bacteriology, vol. 182, no. 3, pp. 573-580, 2000.

[35] D. F. Jin, H. Hu, D. F. Liu, H. T. Ding, X. M. Jia, and Y. H. Zhao, "Optimization of a bacterial consortium for nitrobenzene degradation," Water Science and Technology, vol. 65, no. 5, pp. 795-801, 2012.

[36] Y. Qi, C. Zheng, and Y. Zhang, "Microbial degradation of nitrobenzene by immobilized cells of Micrococcus luteus," Advanced Materials Research, vol. 599, pp. 52-59, 2012.

[37] D. Wang, G. Zheng, and L. Zhou, "Isolation and characterization of a nitrobenzene-degrading bacterium Klebsiella ornithinolytica NB1 from aerobic granular sludge," Bioresource Technology, vol. 110, pp. 91-96, 2012.

[38] Y. Li, H. Hu, and Q. Wu, "Isolation and characterization of psychrotrophic nitrobenzene-degrading strains from river sediments," Bulletin of Environmental Contamination and Toxicology, vol. 79, no. 3, pp. 340-344, 2007.

[39] T. Li, K. Qian, W. Xiao, J. J. Wang, and X. P. Deng, "Biodegradation of nitrobenzene by ahalophilic Myroidesodoratimimus strain Y6," Huan Jing Ke Xue, vol. 34, pp. 753-759, 2013.

[40] N. Liu, H.-J. Li, Y.-E. Shi, B.-L. Zhu, and S. Gao, "Biodegradation of high concentration of nitrobenzene by Pseudomonas corrugata embedded in peat-phosphate esterified polyvinyl alcohol," World Journal of Microbiology and Biotechnology, vol. 29, no. 10, pp. 1859-1867, 2013.

[41] Z. Wu, Y. Liu, H. Liu et al., "Characterization of the nitrobenzene-degrading strain Pseudomonas sp. a3 and use of its immobilized cells in the treatment of mixed aromatics wastewater," World Journal of Microbiology and Biotechnology, vol. 28, no. 8, pp. 2679-2687, 2012.

[42] C. Wei, Y. Hou, Y. Ren, B. Xie, and C. Wu, "Bio-cooperation effect and mixing substrates in the aerobic degradation of nitrobenzene," Zhongguo Huanjing Kexue, vol. 20, pp. 241-244, 2000.

[43] B. E. Haigler and J. C. Spain, "Biotransformation of nitrobenzene by bacteria containing toluene degradative pathways," Applied and Environmental Microbiology, vol. 57, no. 11, pp. 3156-3162, 1991.

[44] J.-S. Zhao and O. P. Ward, "Cometabolic biotransformation of nitrobenzene by 3-nitrophenol degrading Pseudomonas putida 2NP8," Canadian Journal of Microbiology, vol. 46, no. 7, pp. 643652, 2000.

[45] Z. Liu, F. Cui, H. Ma et al., "The transformation mechanism of nitrobenzene in the present of a species of cyanobacteria Microcystis aeruginosa," Chemosphere, vol. 95, pp. 234-240, 2014.

[46] D. Li, M. Yang, Z. Li, R. Qi, J. He, and H. Liu, "Change of bacterial communities in sediments along Songhua River in Northeastern China after a nitrobenzene pollution event," FEMS Microbiology Ecology, vol. 65, no. 3, pp. 494-503, 2008.

[47] L. Levin, A. Viale, and A. Forchiassin, "Degradation of organic pollutants by the white rot basidiomycete Trametes trogii," International Biodeterioration \& Biodegradation, vol. 52, no. 1, pp. 1-5, 2003.

[48] X. Zhang, M. Xu, L. Li, Y. Geng, M. Chen, and J. Wang, "Study on degradation of several poisonous pollutions in environmental by laccase from white rot fungus," Chemistry and Bioengineering, vol. 23, pp. 40-42, 2006.

[49] Z. Chunli, Z. Jiti, W. Jing, and Q. Baocheng, "Isolation and characterization of a nitrobenzene degrading yeast strain from activated sludge," Journal of Hazardous Materials, vol. 160, no. 1, pp. 194-199, 2008.

[50] C. Zheng, J. Zhou, J. Wang, B. Qu, H. Lu, and H. Zhao, "Aerobic degradation of nitrobenzene by immobilization of Rhodotorula mucilaginosa in polyurethane foam," Journal of Hazardous Materials, vol. 168, no. 1, pp. 298-303, 2009.

[51] O. Dickel, W. Haug, and H. J. Knackmuss, "Biodegradation of nitrobenzene by a sequential anaerobic-aerobic process," Biodegradation, vol. 4, no. 3, pp. 187-194, 1993.

[52] W. J. Hua, H. W. Chao, and L. Ping, "The effect of metal ions and salinity on anaerobic biodegradation of nitrobenzene," Research of Environmental Sciences, vol. 22, pp. 99-102, 2009.

[53] H. Liu, S.-J. Wang, and N.-Y. Zhou, "A new isolate of Pseudomonas stutzeri that degrades 2-chloronitrobenzene," Biotechnology Letters, vol. 27, no. 4, pp. 275-278, 2005.

[54] H. Liu, S.-J. Wang, J.-J. Zhang, H. Dai, H. Tang, and N.-Y. Zhou, "Patchwork assembly of nag-like nitroarene dioxygenase genes and the 3-chlorocatechol degradation cluster for evolution of the 2-chloronitrobenzene catabolism pathway in Pseudomonas stutzeri ZWLR2-1," Applied and Environmental Microbiology, vol. 77, no. 13, pp. 4547-4552, 2011.

[55] H. Wu, C. Wei, Y. Wang, Q. He, and S. Liang, "Degradation of $\mathrm{o}$-chloronitrobenzene as the sole carbon and nitrogen sources by Pseudomonas putida OCNB-1," Journal of Environmental Sciences, vol. 21, no. 1, pp. 89-95, 2009.

[56] J.-F. Wu, C.-Y. Jiang, B.-J. Wang, Y.-F. Ma, Z.-P. Liu, and S.-J. Liu, "Novel partial reductive pathway for 4-chloronitrobenzene and nitrobenzene degradation in Comamonas sp. strain CNB1," Applied and Environmental Microbiology, vol. 72, no. 3, pp. 1759-1765, 2006.

[57] D. Zhen, H. Liu, S.-J. Wang, J.-J. Zhang, F. Zhao, and N.-Y. Zhou, "Plasmid-mediated degradation of 4-chloronitrobenzene by newly isolated Pseudomonas putida strain ZWL73," Applied Microbiology and Biotechnology, vol. 72, no. 4, pp. 797-803, 2006.

[58] E. Katsivela, V. Wray, D. H. Pieper, and R.-M. Wittich, "Initial reactions in the biodegradation of 1-chloro-4-nitrobenzene by a newly isolated bacterium, strain LW1," Applied and Environmental Microbiology, vol. 65, no. 4, pp. 1405-1412, 1999.

[59] A. Schackmann and R. Muller, "Reduction of nitroaromatic compounds by different Pseudomonas species under aerobic conditions," Applied Microbiology and Biotechnology, vol. 34, no. 6, pp. 809-813, 1991.

[60] A. Kuhlmann and W. Hegemann, "Degradation of monochloronitrobenzenes by Pseudomonas acidovorans CA50," Acta Hydrochimica et Hydrobiologica, vol. 25, no. 6, pp. 298-305, 1997.

[61] L. Zhang, X. Wang, Y. Jiao et al., "Biodegradation of 4-chloronitrobenzene by biochemical cooperation between Sphingomonas sp. strain CNB3 and Burkholderia sp. strain CAN6 isolated from activated sludge," Chemosphere, vol. 91, no. 9, pp. 1243-1249, 2013.

[62] M. D. Corbett and B. R. Corbett, "Metabolism of 4-chloronitrobenzene by the yeast Rhodosporidium sp," Applied and Environmental Microbiology, vol. 41, no. 4, pp. 942-949, 1981.

[63] C. W. Chambers, H. H. Tabak, and P. W. Kabler, "Degradation of aromatic compounds by phenol-adapted bacteria," Journal (Water Pollution Control Federation), vol. 35, pp. 1517-1528, 1963.

[64] N. G. McCormick, F. E. Feeherry, and H. S. Levinson, "Microbial transformation of 2,4,6-trinitrotoluene and other nitroaromatic compounds," Applied and Environmental Microbiology, vol. 31, no. 6, pp. 949-958, 1976. 
[65] W. R. Mitchell and W. H. Dennis Jr., "Biodegradation of 1,3dinitrobenzene," Journal of Environmental Science and HealthPart A Environmental Science and Engineering, vol. 17, no. 6, pp. 837-853, 1982.

[66] S. Dey, P. Kanekar, and S. H. Godbole, "Aerobic microbial degradation of m-dinitrobenzene," Indian Journal of Environmental Health, vol. 28, no. 2, pp. 118-128, 1986.

[67] O. Dickel and H.-J. Knackmuss, "Catabolism of 1,3-dinitrobenzene by Rhodococcus sp. QT-1," Archives of Micro-biology, vol. 157, no. 1, pp. 76-79, 1991.

[68] R. Boopathy, J. Manning, C. Montemagno, and K. Rimkus, "Metabolism of trinitrobenzene by a Pseudomonas consortium," Canadian Journal of Microbiology, vol. 40, no. 9, pp. 787-790, 1994.

[69] E. P. Davis, R. Boopathy, and J. Manning, "Use of trinitrobenzene as a nitrogen source by Pseudomonas vesicularis isolated from soil," Current Microbiology, vol. 34, no. 3, pp. 192-197, 1997.

[70] N. B. K. Murthy and D. D. Kaufman, "Degradation of pentachloronitrobenzene (PCNB) in anaerobic soils," Journal of Agricultural and Food Chemistry, vol. 26, no. 5, pp. 1151-1156, 1978.

[71] S. Susarla, S. Masunaga, and Y. Yonezawa, "Transformations of chloronitrobenzenes in anaerobic sediment," Chemosphere, vol. 32, no. 5, pp. 967-977, 1996.

[72] D. O. Tas and S. G. Pavlostathis, "Microbial reductive transformation of pentachloronitrobenzene under methanogenic conditions," Environmental Science and Technology, vol. 39, no. 21, pp. 8264-8272, 2005.

[73] S. E. Murphy, A. Drotar, and R. Fall, "Biotransformation of the fungicide pentachloronitrobenzene by Tetrahymena thermophila," Chemosphere, vol. 11, no. 1, pp. 33-39, 1982.

[74] C. I. Chacko, J. L. Lockwood, and M. Zabik, "Chlorinated hydrocarbon pesticides: degradation by microbes," Science, vol. 154, no. 3751, pp. 893-895, 1966.

[75] T. Nakanishi and H. Oku, "Metabolism and accumulation of pentachloronitrobenzene by phytopathogenic fungi in relation to selective toxicity.", Phytopathology, vol. 59, no. 11, pp. 1761$1762,1969$.

[76] D. Lièvremont, F. Seigle-Murandi, J.-L. Benoit-Guyod, and R. Steiman, "Biotransformation and biosorption of pentachloronitrobenzene by fungal mycelia," Mycological Research, vol. 100, no. 8, pp. 948-954, 1996.

[77] D. Lièvremont, F. Seigle-Murandi, and J.-L. Benoit-Guyod, "Removal of PCNB from aqueous solution by a fungal adsorption process," Water Research, vol. 32, no. 12, pp. 3601-3606, 1998.

[78] K. Takagi, A. Iwasaki, I. Kamei, K. Satsuma, Y. Yoshioka, and N. Harada, "Aerobic mineralization of hexachlorobenzene by newly isolated pentachloronitrobenzene-degrading Nocardioides sp. strain PD653," Applied and Environmental Microbiology, vol. 75, no. 13, pp. 4452-4458, 2009.

[79] K. Takagi, R. Kataoka, and K. Yamazaki, "Recent technology on bio-remediation of POPs and persistent pesticides," Japan Agricultural Research Quarterly, vol. 45, no. 2, pp. 129-136, 2011.

[80] R. Li, J.-W. Zheng, B. Ni et al., "Biodegradation of Pentachloronitrobenzene by Labrys portucalensis pcnb-21 Isolated from Polluted Soil," Pedosphere, vol. 21, no. 1, pp. 31-36, 2011.

[81] R. E. Parales, R. Huang, C.-L. Yu et al., "Purification, characterization, and crystallization of the components of the nitrobenzene and 2-nitrotoluene dioxygenase enzyme systems," Applied and Environmental Microbiology, vol. 71, no. 7, pp. 3806-3814, 2005.
[82] D. J. Lessner, G. R. Johnson, R. E. Parales, J. C. Spain, and D. T. Gibson, "Molecular characterization and substrate specificity of nitrobenzene dioxygenase from Comamonas sp. strain JS765," Applied and Environmental Microbiology, vol. 68, no. 2, pp. 634641, 2002.

[83] Y. Zhang, J.-F. Wu, J. Zeyer et al., "Proteomic and molecular investigation on the physiological adaptation of Comamonas sp. strain CNB-1 growing on 4-chloronitrobenzene," Biodegradation, vol. 20, no. 1, pp. 55-66, 2009.

[84] L. Liu, J.-F. Wu, Y.-F. Ma, S.-Y. Wang, G.-P. Zhao, and S.-J. Liu, "A novel deaminase involved in chloronitrobenzene and nitrobenzene degradation with Comamonas sp. strain CNB-1," Journal of Bacteriology, vol. 189, no. 7, pp. 2677-2682, 2007.

[85] Y. Xiao, J.-F. Wu, H. Liu, S.-J. Wang, S.-J. Liu, and N.-Y. Zhou, "Characterization of genes involved in the initial reactions of 4-chloronitrobenzene degradation in Pseudomonas putida ZWL73," Applied Microbiology and Biotechnology, vol. 73, no. 1, pp. 166-171, 2006.

[86] Y.-F. Ma, J.-F. Wu, S.-Y. Wang et al., "Nucleotide sequence of plasmid pCNB1 from Comamonas strain CNB-1 reveals novel genetic organization and evolution for 4-chloronitrobenzene degradation," Applied and Environmental Microbiology, vol. 73, no. 14, pp. 4477-4483, 2007.

[87] D. Zhen, H. Liu, S.-J. Wang, J.-J. Zhang, F. Zhao, and N.-Y. Zhou, "Plasmid-mediated degradation of 4-chloronitrobenzene by newly isolated Pseudomonas putida strain ZWL73," Applied Microbiology and Biotechnology, vol. 72, no. 4, pp. 797-803, 2006. 

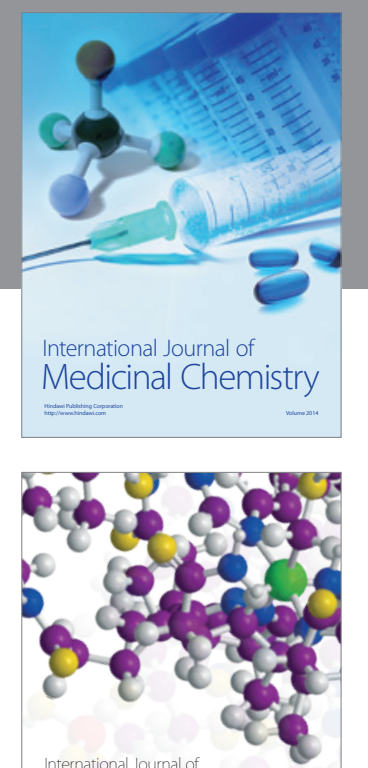

\section{Carbohydrate} Chemistry

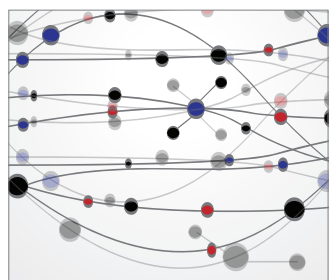

The Scientific World Journal
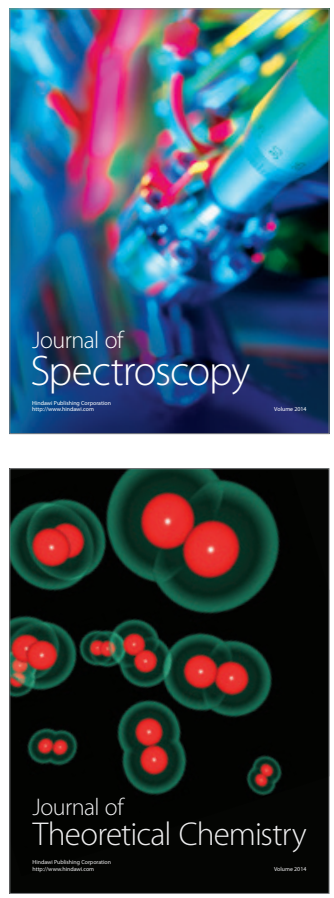
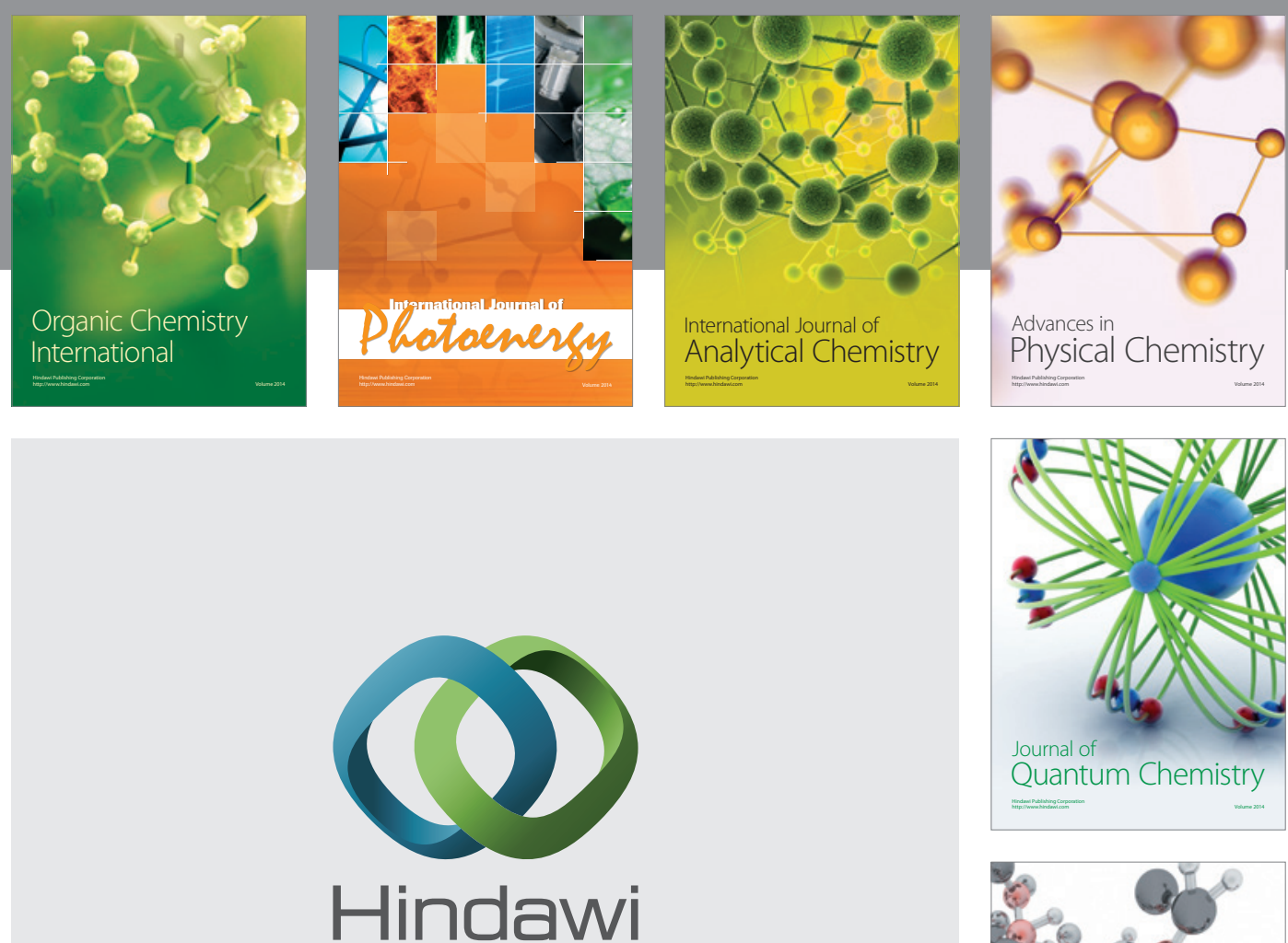

Submit your manuscripts at

http://www.hindawi.com

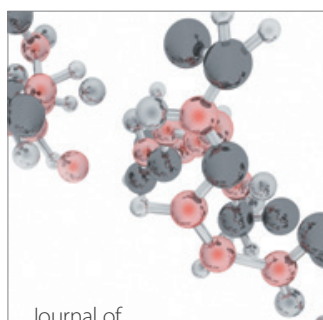

Analytical Methods

in Chemistry

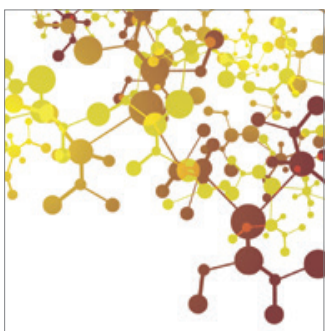

Journal of

Applied Chemistry

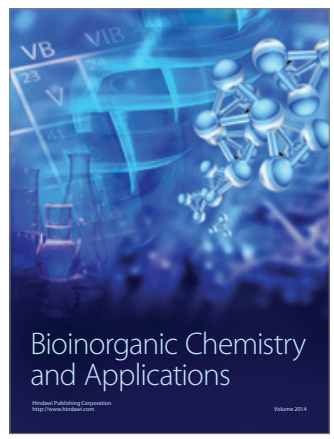

Inorganic Chemistry
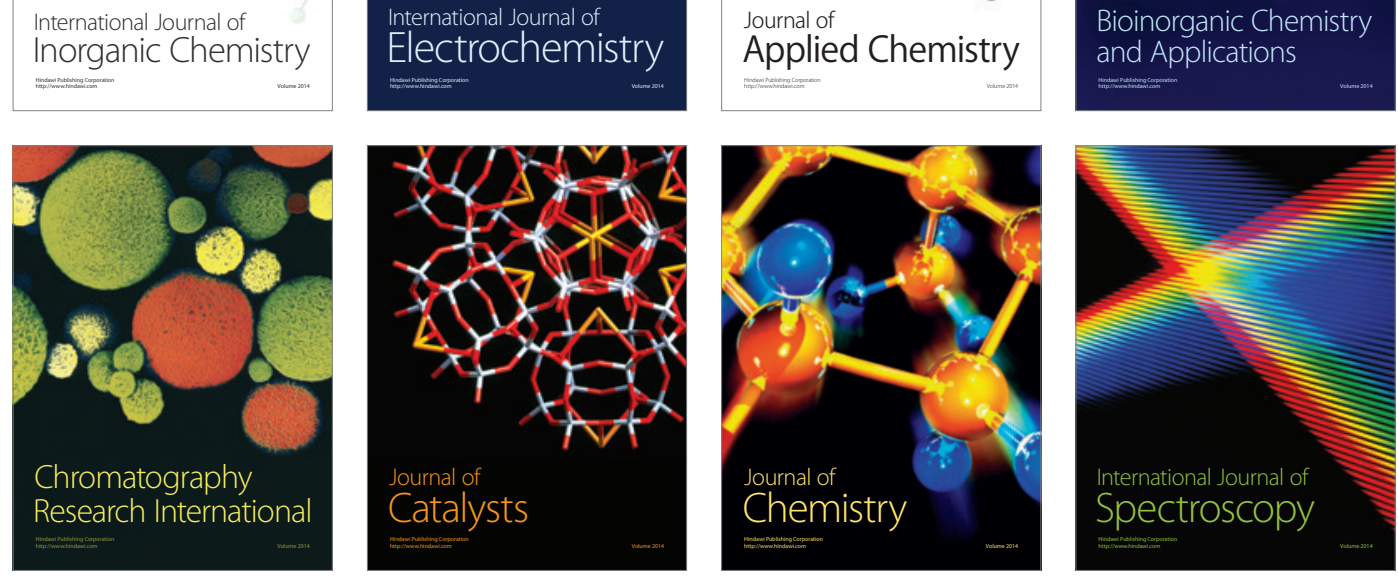